\title{
CASE STUDY: FILM CENSORSHIP IN INDIA
}

\author{
Aditya Kumar Panda \\ National Translation Mission \\ Central Institute of Indian Languages \\ Mysore-570006, India.
}

\begin{abstract}
Censorship is a controlling force of an authority. It is structured and determined by an authority that is governed by socio political and religious forces of a nation. The paper studies the prevailing practices on film censorship in India. It highlights the causes behind the film censorship in India which has been a topic of current affairs in the $21^{\text {st }}$ century.
\end{abstract}

KEYWORDS: censorship, films, politics, religion, sexuality, India

\section{Introduction}

Censorship is a phenomenon found in the context of an authority and its exercise of freedom over its subjects. An authority interacts with its subjects through various media (print media in the form of newspapers, books, documents or audio-visual media like tv programs, films etc). Media are the ways to control, to motivate, to inform the subjects. No medium has a static function and a medium is not merely a medium. People watch a film maybe for entertainment, but a film provides information or motivation while entertaining them. A medium exists in a pluralsphere, it has more than one purpose, it has more than one element, it has more than one structure, more than one reading. A film as a medium may record a history, may produce a new tradition, may write geography newly, may create awareness, may add to a scientific discovery so on and so forth. As it is one of the most alluring audio-visual medium, it has the maximum effect on the people. If the effect violates the prescribed norms of an authority, the authority censors the effect-producing films. According to the Supreme Court of India, film censorship becomes necessary because a film motivates thought and action and assures a high degree of attention and retention as compared to the printed word ${ }^{l}(C B F C$, India).This paper will discuss about the film censorship in India.

\section{Discussion:}

The Oxford Dictionary of English ${ }^{2}$ defines censorship as the suppression or prohibition of any parts of books, films, news, etc. that are considered obscene, politically unacceptable, or a threat to security. By the end of 2014 ,there came a controversy over Amir Khan's PK, a Hindi movie in India. The controversy was whether it should be banned or it should be allowed to be watched in many Indian states. Mostly who were bringing a ban over PK were the Indians who thought that their religious sentiments had been mocked at or caricatured. In spite of these controversies, it became a hit in India. It shows that individually every Indian likes to watch the movie. A common man who knew what entertainment was but did not know what this controversy was, went to a cinema hall and watched it or bought a CD and watched it. Sometimes such banning is caused by invisible forces which are driven by market or which are genuinely driven by religious sentiments.

${ }^{1}$ Central Board of Film Certification, Ministry of Information And Broadcasting, Government of India, 2012

${ }^{2}$ Dictionary, Oxford English."OED online."Oxford University Press. http://www. oed. com, Accessed April 21, 2016. 
Censorship is never felt individually, it is always a subject where the forces of community or a group could be seen. We all watch movies, we all read books. Watching movie is an individual experience; it can be watched in a group, sitting in a theater with $200-500$ people. But all 200-500 people do have 200 or 500 experiences of watching a movie. Then the question comes, who finds out the filthy affair? No individual, but individuals with groups. If we analyze the history of film censorship in India, one can state that a film is banned or censored on the following reasons: i) Sexuality, ii) Politics, iii) Religion, iv) Communal conflict, v) incorrect portrayal of someone or something, vi) extreme violence

i) Sexuality: Indian society has been following a rigid social structure. Marriage is a social institution where it has allowed sexual relationship between a man and a woman, although human beings do have other forms of sexual relationship like homosexual, lesbian, which have been discarded by Indian society or Freudian concept of Oedipal longing has been highly criticized. A medium whether written or audio-visual portraying sexuality which has not been accepted by Indian society openly is banned on the ground that it may degrade the morals of Indians. On this ground, Kamasutra, an erotic film was banned in India because of its depiction of sexual and homosexual contents. Deepa Mehta's Fire ${ }^{3}$ was banned in India as it depicted lesbian relationship. It was one of the first films that showed explicit homosexual relationship. There were huge protests against the film by the Hindu fundamentalists. It was again sent back to the Censor Board, but later it was released by changing the name of the character Sita to Nita. The Pink Mirror (GulabiAaina) ${ }^{4}$, a 2004 film was banned in India for its depiction of transsexual contents. The Girl with the Dragon Tattoo ${ }^{5}$ was banned for its adult scenes of rape and torture. In shooting set,the movie, Water, faced objections from many Hindu organizations in Varanasi, as it depicted controversial subject like misogyny and ostracism. Later it was shifted to Srilanka. Sexuality has never been discussed openly in India. Some religions completely discourage all forms of sexuality. It is a fact in our day today life which is always kept secret. Even imparting sex education in Indian schools has been in the debate but has not been made a part of the syllabi.

ii) Politics: Political forces cannot be isolated as far as the topic of censorship is concerned. Censoring a film by a political state is always supported by the parties who are with the authority directly or indirectly. A medium describing a political situation allegorically or directly is banned by a government who is a party to it. It may be an international political issue like the Neel AkasherNeechey. Neel AkasherNeechey was a Bengali language film directed by Mrinal Sen was the first film to be banned by the Government of India because of its overt political overtones $^{6}$. Its background was set in the last days of British Raj in Calcutta (Kolkata) when the freedom struggle was at its pick. The film was about Wang lu, a Chinese man who was an immigrant wage labor and his relationship with Basanti, a house wife in Calcutta. Gokul Shankar ${ }^{7}$, was banned in 1963 by Government of India for portraying the psychological motivations behind NathuramGodse's assassination of Mahatma Gandhi. GaramHawa ${ }^{8}$, a 1973 Hindi-Urdu film, was directed by M.S. Sathyu. It was based on an unpublished short story by IsmatChughtai. It was about the fate of a North Indian Muslim businessman and his family in the tragic time of partition. Censor board ofIndia banned it for 8 months thinking that it might cause communal unrest but later it was released.Aandhi ${ }^{9}$, a 1975 film which was thought to be an allegory of then the Prime Minister of India, Indira Gandhi was banned by Indira Gandhi during the national emergency of 1975 . When Janata Party came to power, it was released in 1977.KissaKursiKa ${ }^{10}$, a satirical film on the politics of Indira Gandhi and her son, Sanjaya Gandhi; was banned by the Congress government during the emergency period. There were 51 objections and the director was asked to give explanation. Sikkim,a 1971 documentary film, directed by Satyajit Ray; was a commissioned film by then the king

\footnotetext{
${ }^{3}$ Jain, Madhu, Raval, Sheela, Ire over Fire. India Today.December 1998.

${ }^{4}$ Sukumaran, Shradha. "Making the Cuts-On Film Censorship in India". YIDFF

Review.http://www.yidff.jp/docbox/22/box22-2-e.html, Accessed 22nd April, 2016

${ }^{5}$ Fincher, David, "The Girl with the Dragon Tattoo cancelled in India". Guardian News and Media Limited,http://www.theguardian.com/film/2012/jan/30/girl-dragon-tattoo-cancelled-india, Accessed April 22, 2016

${ }^{6}$ Bobb, Dilip."The cinema of 'bad light'".The Indian Express. 13 August 2011

${ }^{7}$ http://www.gutenberg.us/articles/list_of_films_banned_in_india\#cite_note-Roger2004-1

${ }^{8}$ Daiya, Kavita. Violent belongings: partition, gender, and national culture in postcolonial India. Temple University Press, 2011.

${ }^{9}$ Sinha, Sayoni, "Controversial Films", https://in.movies.yahoo.com/blogs/24fps/controversial-films061836779.html?page=all, Accessed April 22, 2016

${ }^{10}$ Kumar, Anuj, "Ban Culture goes back a long way". The Hindu. February 2013
} 
of Sikkim when he felt that Sikkim was under threat from both India and China. It was banned by the government of India when Sikkim was merged with India in 1975. In 2010, the ban was lifted.Kuttrapathirikai ${ }^{11}$, a Tamil drama film was not released until 2007, as it had the issues of the assassination of Rajiv Gandhi and the Srilankan civil war.Aarakshan ${ }^{12}$, the Hindi movie was banned in Andhra Pradesh, Uttar Pradesh and Punjab with the concern that it may hurt the weaker sections of the society as it deals with politics over reservation in educational institutions. In the early part of June, 2016, we saw a controversy over the film Udta Punjab, directed by AbhisekChaubey. CBFC decided to have the film released with some cuts. It was a drug-themed film with particular reference to Punjab. Punjab and Haryana high courts also issued show-cause notice to the government of India, the CBFC and the producers. The film was considered to have some negative portrayal of the Punjabis and Punjab.

iii) Religion: Religion as an institution does not approve any kind of disobedience towards the values it propagates. Any medium that distorts the religious characters of a religion is criticized and censored by the same. Religious sentiment does cause film censorship in India. Indiana Jones and the Temple of Doom ${ }^{13}$, a 1984 American adventure film which was banned temporarily by the government of India as it depicted the goddess Kali as a representative of underworld. Censor Board took a note of religious sentiment and put a ban on it. Yvette Claire Rosser, a famous American writer criticizes the film as it depicts Indians not what they are but what they are in the Westerner's eyes. In 2006, The Da Vinci Code was banned in Andhra Pradesh, Tamil Nadu, Nagaland, Goa, and Punjab with the concern that the film might hurt religious sentiments of the Christians. The recent controversy over PK also falls under this category.

iv) CommunalConflict: A film is also censored if it incites any kind of communal conflict under a heterogeneous nation. Heterogeneity is a feature of India as a nation. FinalSolution ${ }^{14}$, a 2004 documentary film was banned by the Censor Board of India as it was based on the Gujarat riots. It was thought that the film might bring huge communal riots.Hawayein ${ }^{15}$, a 2003 bollywood film, was banned in Delhi, Haryana and Punjab as it set against the backdrop to the 1984 Sikh genocide ${ }^{16}$. Another film, entitled Amu on the November event of 1984 Sikh riots was allowed by the Censor Board of India with some audio cuts ${ }^{17}$.In 2013, Vishwaroopam ${ }^{18}$ was banned as the objection was received from Muslim groups regarding their portrayal.

v) Incorrect Portrayal of a Popular Figure: Sometime it is a popular man who objects to his own depiction in a medium and goes for censoring it. Bandit Queen ${ }^{19}$, a biographical film based on Phoolan Devi, was banned temporarily by the Delhi High Court after Phoolan Devi sued a case against its authenticity. Main Hoon Rajinikanth $^{20}$, a Hindi comedy film was criticized by Rajnikanth who went to High Court to stop its relese. Rajanikanth thought the film may spoil his image. The film, Jodhaa Akbar ${ }^{21}$, was banned after Rajput's community's protest over Jodha Bai's depiction as Akbar's wife. Later it was released.

\footnotetext{
${ }^{11}$ High Court judges to see `Kutrapathirikkai'http://www.thehindu.com/todays-paper/tp-national/tptamilnadu/article3050604.ece, Accessed, 22 April, 2016

${ }^{12}$ Lift the Ban, the Hindu, http://www.thehindu.com/opinion/editorial/lift-the-ban/article2351412.ece, Accessed, April 22, 2016

${ }^{13}$ Signore, John Del. "Brewery Apologizes To Hindus For Temple Of Doom-Inspired "Kali-Ma" Beer". www.gothamist.com, May 15,2012

${ }^{14}$ Patwardhan, Anand, "Freedom of Expression and the Politics of Art", Films of AnandPatwardhan, 2014

${ }^{15}$ Tyagi, Rajeev. "Winds of Change", Midday Infomedia Ltd, 20 February, 2010

${ }^{16}$ ibid

${ }^{17}$ Deshpande, Sudhanva. "The Children of 1984", The Frontline, Vol 22, Issue 04, February, 2005

${ }^{18}$ Vishwaroopam: Madras HC upholds ban, Kamal Haasan to move SC, The Times of India, http://timesofindia.indiatimes.com/india/Vishwaroopam-Madras-HC-upholds-ban-Kamal-Haasan-to-move-

SC/articleshow/18255485.cms?referral=PM, Accessed 22 April, 2016

${ }^{19}$ Moxham, Roy. Outlaw: India's Bandit Queen and me, RIDER, 2010. Print.

${ }^{20}$ Subramani, A. "Superstar Rajinikanth gets stay on release of Bollywood movie named after him", The Times of India, 17 September, 2014.

${ }^{21}$ Jodhaa Akbar banned in Madhya Pradesh after Rajput protests, The Times of India, http://timesofindia.indiatimes.com/india/Jodhaa-Akbar-banned-in-Madhya-Pradesh-after-Rajputprotests/articleshow/2805189.cms, Accessed 22 April,2016
} 
vi) ExtremeViolence:Portraying extreme violence disturbs human mind. One of the primary purposes of watching films is entertainment although violence is a fact of life. Portraying extreme violence in films affects the people psychologicallyPaanch $^{22}$ is an unreleased Indian film. It was directed by AnuragKashyap.The Central Board of Film Certification objected to its depiction of violence.But later it was allowed to be released with cuts but could not get released.

These bannings are from an authority, an organization, a board or a court or by a popular individual. First question comes to my mind is: do the things exist in India that the films portray? We cannot take up biographical films into account, as their authorities are the authors. But consider the politics over reservation, deception in the name of religion, changing sexual scenario of India, communal riots, changing life-style in India. An Indian who witnesses all these happening in day- to-day life cannot deny it, when it is portrayed in a film. Above all, film is an effective media and as entertainment is attached to it, it allures all from a child to an old man. Although freedom of speech is a fundamental right in the Constitution of India, it does not allowindividuals the right freely, clause-2 of article 19 of the constitution of India restricts the freedom of speech on the following subjects: I. security of the State, II. Friendly relations with foreign States, III.Public order, IV. Decency and morality, V. contempt of court, VI. Defamation, VII.Incitement to an offence, and VIII.Sovereignty and integrity of India.As per the IT rules,2011, the content which "threatens the unity, integrity, defense, security or sovereignty of India, friendly relations with foreign states or public order" has to be objected. The Central Board of Film Certification allows some films with explicitly sexual content but such films should be shown only in restricted places and to the people above 18 yrs.

\section{Conclusion:}

Censorship is a control of an authority over its subjects. An authority is always political and it prescribes various norms for its subjects to rule them in a desired designed way. Although an authority is made of the people under it, the authority is an artificial construct in a civilization. This is why the norms can be challenged. What is censored today may not be censored tomorrow. The way the films are censored in India witnesses the continuity of the traditionally followed norms in India and reinforces the same. Norms may not necessarily be static, they may change in time. The reality is always ahead with the prescribed norms which may result in modifying the same under an authority. Exhibiting homosexual relationship through a film in India goes against the prescribed norms at present, but the same norm will be changed in a time when it will be a realized reality.

\section{References:}

1. Bobb, Dilip."The cinema of 'bad light'".The Indian Express. 13 August 2011

2. Central Board of Film Certification, Ministry of Information And Broadcasting, Government of India, 2012

3. Cinematograph Act, 1952 and 1983, Government of India

4. Dictionary, Oxford English."Oxford English dictionary online."Oxford University Press, 2016.

5. Deshpande, Sudhanva. "The Children of 1984", The Frontline, Vol 22, Issue 04, February, 2005

6. Dictionary, Oxford English."OED online."Oxford University Press. http://www. oed. com, Accessed April 21, 2016.

7. Daiya, Kavita. Violent belongings: partition, gender, and national culture in postcolonial India. Temple University Press, 2011.

8. Fundamental Rights, Constitution of India-Part III, Article 19

9. Fincher, David, "The Girl with the Dragon Tattoo cancelled in India". Guardian News and Media Limited,http://www.theguardian.com/film/2012/jan/30/girl-dragon-tattoo-cancelled-india, Accessed April 22, 2016

10. High Court judges to see `Kutrapathirikkai'http://www.thehindu.com/todays-paper/tp-national/tptamilnadu/article3050604.ece, Accessed, 22 April, 2016

11. Jain, Madhu, Raval, Sheela, "Ire over Fire". India Today. 21 December, 1998

12. Jodhaa Akbar banned in Madhya Pradesh after Rajput protests, The Times of India, http://timesofindia.indiatimes.com/india/Jodhaa-Akbar-banned-in-Madhya-Pradesh-after-Rajputprotests/articleshow/2805189.cms, Accessed 22 April,2016

13. Joshi, Namrata, "Rock 'N' Roll Banned", The Outlook, 3 September, 2001

\footnotetext{
${ }^{22}$ Joshi, Namrata, "Rock 'N' Roll Banned", The Outlook, 3 September, 2001
} 
14. Kumar, Anuj, "Ban Culture goes back a long way". The Hindu. February 2013

15. Lift the Ban, the Hindu, http://www.thehindu.com/opinion/editorial/lift-the-ban/article2351412.ece, Accessed, April 22, 2016

16. Mehta, Monika. "What is behind film censorship? The Khalnayak debates." Jouvert: A Journal of Postcolonial Studies 5.3 (2001): 1-12.

17. Moxham, Roy. Outlaw: India's Bandit Queen and me, RIDER, 2010. Print.

18. Patwardhan, Anand, "Freedom of Expression and the Politics of Art", Films of AnandPatwardhan, 2014

19. Sukumaran, Shradha. "Making the Cuts-On Film Censorship in India". YIDFF Review.http://www.yidff.jp/docbox/22/box22-2-e.html, Accessed 22nd April, 2016

20. Sinha,Sayoni,"ControversialFilms", https://in.movies.yahoo.com/blogs/24fps/controversial-films061836779.html?page=all, Accessed April 22, 2016

21. Subramani, A. "Superstar Rajinikanth gets stay on release of Bollywood movie named after him", The Times of India, 17 September, 2014.

22. Signore, John Del. "Brewery Apologizes To Hindus For Temple Of Doom-Inspired "Kali-Ma" Beer". www.gothamist.com, May 15,2012

23. Tyagi, Rajeev. "Winds of Change", Midday Infomedia Ltd, 20 February, 2010

Vishwaroopam: Madras HC upholds ban, Kamal Haasan to move SC, The Times of India, http://timesofindia.indiatimes.com/india/Vishwaroopam-Madras-HC-upholds-ban-Kamal-Haasan-to-moveSC/articleshow/18255485.cms?referral=PM, Accessed 22 April, 2016

Row over 'Udta Punjab' escalates,Kashyap calls Censor,

chiefhttp://www.deccanchronicle.com/entertainment/bollywood/070616/row-over-udta-punjab-escalates-kashyapcalls-censor-chief.html, accessed 14 June, 2016 